\title{
Kematian akibat kecelakaan lalu lintas Kota Tomohon tahun 2012-2014
}

\author{
${ }^{1}$ Arischa Rompis \\ ${ }^{2}$ Johannis Mallo \\ ${ }^{2}$ Djemi Tomuka
}

\author{
${ }^{1}$ Kandidat Skripsi Fakultas Kedokteran Universitas Sam Ratulangi Manado \\ ${ }^{2}$ Bagian Ilmu Kedokteran Forensik dan Medikolegal Fakultas Kedokteran \\ Universitas Sam Ratulangi Manado \\ Email: arischakristanty@gmail.com
}

\begin{abstract}
Traffic accident as a health problem being the most causal factor of injury in the world. Most cases of injuries occur in the age range 15-44 years and are dominated by man with disability proportion and also that of traffic accident around $25 \%$. The most important factor who determine level of accident distribution by human error who contribute $75-80 \%$ and also affected by disciplinary factor in driving (80-90\%), vehicle factor (4\%), the road (3\%), and environment factor $(1 \%)$. This study aimed to obtain some information about the death caused by traffic accident in Tomohon city between the years 2012-2014. This was a descriptive retrospective study using data of Police Department in Tomohon from October to November 2015. The results showed that the peak of deaths due to traffic accidents in Tomohon city (2012-2014) was in 2013 with 50 male victims from 59 victims aged 15-24 years. Most of the victims were motorcycle drivers.
\end{abstract}

Keywords: death, traffic accident

\begin{abstract}
Abstrak: Kecelakaan lalu lintas merupakan masalah kesehatan yang menjadi penyebab terbanyak terjadinya cedera di seluruh dunia. Kasus cedera terbanyak terjadi pada rentang usia 15 - 44 tahun yang didominasi kaum pria dengan proporsi disabilitas dan kematian karena kecelakaan sekitar 25\%. Faktor yang dianggap menentukan tingginya jumlah kecelakaan dan keparahan korban kecelakaan yaitu faktor manusia yang memberikan kontribusi $75-80 \%$ yang juga dipengaruhi oleh faktor kedisiplinan dalam berkendara (80-90\%), faktor kendaraan (4\%), faktor jalan (3\%), dan faktor lingkungan (1\%). Penelitian ini bertujuan untuk mengetahui informasi mengenai kematian akibat kecelakaan lalu lintas di kota Tomohon tahun 2012 - 2014. Metode penelitian yang digunakan adalah metode deskriptif retrospektif yang dilakukan di bagian lalu lintas POLRESTA TOMOHON pada bulan Oktober - November 2015. Hasil yang diperoleh dari penelitian ini menggambarkan kematian akibat kecelakaan lalu lintas di kota Tomohon 2012 - 2014 mengalami puncak kenaikan pada tahun 2013 dengan korban terbanyak laki - laki dan berada direntang usia 15 - 24 yang berstatus sebagai pengendara sepeda motor. Lokasi kejadian kecelakaan tersering di wilayah Tomohon Tengah yang didominasi jalan dalam kota.
\end{abstract}

Kata kunci: kematian, kecelakaan lalu lintas

Kecelakaan lalu lintas merupakan masalah kesehatan yang menjadi penyebab terbanyak terjadinya cedera di seluruh dunia. Cedera akibat kecelakaan lalu lintas menjadi penyebab utama kematian dan disabilitas. Data WHO mencatatat bahwa Negara - negara dengan tingkat pendapatan perkapita tinggi seperti Amerika, jumlah kematian akibat kecelakaan lalu lintas menempati peringkat ke - 14 dengan kematian rata - rata 15,0 per 100.000 penduduk. Sedangkan di Eropa 11,2 per 100.000 penduduk. Negara- negara dengan tingkat pendapatan perkapita rendah cenderung memiliki prevalensi yang lebih tinggi yaitu menempati urutan ke -10 penyebab kematian., ${ }^{1,2}$ Tercatat 1,21 juta jiwa tewas setiap tahunnya dan sebanyak 
63.013 korban luka - luka/cacat akibat kecelakaan lalu lintas tiap harinya. ${ }^{1}$ Sebanyak 6.142 orang mengalami luka berat, 8.694 luka ringan, dengan rata - rata kejadian 40 setiap hari yang mengakibatkan 30 orang mati. ${ }^{2,3}$ Kasus cedera terbanyak terjadi pada rentang usia 15 - 44 tahun yang didominasi kaum pria dengan proporsi disabilitas dan kematian karena kecelakaan yaitu sekitar $25 \%{ }^{4-7}$ Faktor yang dianggap menentukan tingginya jumlah kecelakaan dan keparahan korban kecelakaan yaitu faktor manusia yang memberikan kontribusi $75-80 \%$ juga dipengaruhi oleh faktor kedisiplinan dalam berkendara (80-90\%), faktor kendaraan (4\%), faktor jalan (3\%), dan faktor lingkungan (1\%).

Peninjauan tempat kejadian perkara oleh ahli kedokteran forensik, yang telah memeriksa atau akan memeriksa jenazah korban atau korban yang terluka, sangat membantu untuk merekonstruksi keadaan saat kecelakaan. Investigasi kasus kecelakaan lalu lintas mempunyai beberapa tujuan, yaitu untuk mengidentifikasi penyebab kecelakaan; memperhitungkan bentuk kompensasi yang sesuai bagi korban, jika hidup, atau bagi sanak keluarga, jika korban meninggal; menghukum pelanggar, jika memang ada pelanggaran terhadap peraturan perundang -undangan yang berlaku; mencari pedoman terhadap pencegahan kecelakaan di masa mendatang. ${ }^{10}$

Kota Tomohon adalah salah satu kota di provinsi Sulawesi Utara yang terletak 23 km dari kota Manado sebagai ibukota provinsi Sulawesi Utara. Luas kota Tomohon berdasarkan keputusan Undang Undang Republik Indonesia Nomor 10 tahun 2003 yaitu sekitar 11.420 Ha dengan jumlah penduduk mencapai 87.719 jiwa. Kota Tomohon menjadi daerah otonom (kota) dengan disahkannya UU Nomor 10 tahun 2003 tentang pembentukan kabupaten Minahasa Selatan dan Kota
Tomohon di provinsi Sulawesi Utara oleh DPR RI, namun peresmiannya baru pada tanggal 4 Agustus 2003. ${ }^{11}$

Data korban mati akibat kecelakaan lalu lintas di kota Tomohon masih terbatas sehingga penelitian ini bertujuan untuk mengetahui informasi mengenai kematian akibat kecelakaan lalu lintas di kota Tomohon dan prevalensi korban mati akibat kecelakaan lalu lintas di kota Tomohon tahun 2012 - 2014 sehingga dapat dilakukan upaya - upaya pencegahan dan pengendalian kasus kecelakaan lalu lintas oleh pihak - pihak terkait.

\section{METODE PENELITIAN}

Metode penulisan yang dilakukan adalah penelitian yang bersifat deskriptif cross sectional (retrospektif). Penelitian deskriptif retrospektif merupakan penelitian yang meninjau data - data pada masa lampau. Penelitian deskriptif dilakukan dengan memberi gambaran yang lebih detail tentang suatu fenomena. Sehingga dari data yang diperoleh dapat menjawab tujuan utama dari penelitian tersebut yaitu untuk mengetahui distribusi kematian akibat kecelakaan lalu lintas di kota Tomohon tahun 2012-2014. Dalam penelitian sampel yang diambil adalah korban mati akibat kecelakaan lalu lintas di kota Tomohon periode tahun 2012 - 2014.

Variabel penelitian yang diteliti terdiri dari jumlah korban mati akibat kecelakaan berdasarkan tingkat keparahan, jenis kelamin, umur, pendidikan, status korban sebelum mati, situasi saat kecelakaan, lokasi, jenis tabrakan, serta jenis kendaraan yang terlibat kecelakaan. Cara kerja yang dipakai pada penelitian ini terdiri dari, pengumpulan data secara retrospektif dari data yang ada di bagian lalu lintas Polresta Tomohon tahun 2012 - 2014, dan pengolahan data dilakukan secara manual dan komputerisasi serta disajikan dalam bentuk Tabel. 
Jurnal e-Clinic (eCl), Volume 4, Nomor 1, Januari-April 2016

HASIL PENELITIAN

Tabel 1. Jumlah kecelakaan lalu lintas di Kota Tomohon periode 2012 - 2014

\begin{tabular}{cc}
\hline Tahun & $\begin{array}{c}\text { Jumlah } \\
\text { Kecelakaan }\end{array}$ \\
\hline 2012 & $121(29,73 \%)$ \\
2013 & $171(42,01 \%)$ \\
2014 & $115(28,26 \%)$ \\
Total & $407(100 \%)$ \\
\hline
\end{tabular}

Tabel 2. Jumlah korban Kecelakaan Lalu Lintas di Kota Tomohon tahun 2012 - 2014

\begin{tabular}{c|cccc}
\hline \multirow{2}{*}{ Tahun } & \multicolumn{4}{|c}{ Korban } \\
\cline { 2 - 4 } & Mati & $\begin{array}{c}\text { Luka } \\
\text { Ringan }\end{array}$ & Luka Berat & Total \\
\hline 2012 & 15 & 184 & 20 & 219 \\
2013 & 30 & 212 & 9 & 251 \\
2014 & 14 & 139 & 1 & 154 \\
Total & 59 & 535 & 30 & 624 \\
$(\%)$ & 9,46 & 85,74 & 4,81 & 100 \\
\hline
\end{tabular}

Tabel 3 Jumlah korban mati akibat kecelakaan lalu lintas berdasarkan jenis kelamin

\begin{tabular}{c|c|c|c}
\hline Tahun & Perempuan & Laki - Laki & $(\%)$ \\
\hline 2012 & 1 & 14 & 15 \\
2013 & 6 & 24 & 30 \\
2014 & 2 & 12 & 14 \\
Total & 9 & 50 & 59 \\
$(\%)$ & 15,25 & 84,75 & 100 \\
\hline
\end{tabular}

Tabel 4. Jumlah korban mati akibat kecelakaan berdasarkan Usia

\begin{tabular}{|c|c|c|c|}
\hline \multirow[t]{2}{*}{ Umur } & \multicolumn{2}{|c|}{ Tahun } & (\%) \\
\hline & 2013 & 2014 & \\
\hline$<1$ & 0 & 0 & - \\
\hline $1-4$ & 0 & 1 & $1(1,69)$ \\
\hline $5-14$ & 2 & 0 & $3(5,08)$ \\
\hline $15-24$ & 16 & 5 & $25(42,37)$ \\
\hline $25-44$ & 6 & 5 & $16(27,12)$ \\
\hline $45-64$ & 6 & 2 & $11(18,64)$ \\
\hline$>65$ & 0 & 1 & $3(5,08)$ \\
\hline Total & 30 & 14 & 59 (100) \\
\hline
\end{tabular}

Tabel 5. Jumlah korban mati akibat kecelakaan berdasarkan tingkat pendidikan

\begin{tabular}{|c|c|c|c|c|c|c|c|}
\hline \multirow[t]{2}{*}{ Tahun } & \multicolumn{6}{|c|}{ Tingkat Pendidikan } & \multirow[t]{2}{*}{ Total } \\
\hline & TK & SD & SMP & SMA & PT & Lain & \\
\hline 2012 & 0 & 2 & 4 & 6 & 3 & 0 & 15 \\
\hline 2013 & 0 & 6 & 3 & 17 & 4 & 0 & 30 \\
\hline 2014 & 0 & 0 & 4 & 8 & 1 & 1 & 14 \\
\hline
\end{tabular}


Rompis, Mallo, Tomuka: Kematian akibat kecelakaan...

$\begin{array}{llllllll}\text { Total } & - & 8 & 11 & 31 & 8 & 1 & 59\end{array}$

$\begin{array}{lllllll}(\%) & 13,56 & 18,64 & 52,54 & 13,56 & 1,69 & 100\end{array}$

Tabel 6. Jumlah korban mati akibat kecelakaan berdasarkan status korban sebelum mati

\begin{tabular}{ccccc}
\hline Tahun & Pengemudi & $\begin{array}{c}\text { Pejalan } \\
\text { Kaki }\end{array}$ & Penumpang & Total \\
\hline 2012 & 9 & 4 & 2 & 15 \\
2013 & 21 & 3 & 6 & 30 \\
2014 & 10 & 3 & 1 & 14 \\
Total & 40 & 10 & 9 & 59 \\
$(\%)$ & 67,80 & 16,95 & 15,25 & 100 \\
\hline
\end{tabular}

Tabel 7 Jumlah kasus kecelakaan lalu lintas dengan korban mati berdasarkan jenis tabrakan

\begin{tabular}{c|c|c|c|c}
\hline Jenis Tabrakan & \multicolumn{3}{|c|}{ Tahun } & $\begin{array}{c}\text { Total } \\
(\%)\end{array}$ \\
\cline { 2 - 5 } & 2012 & 2013 & 2014 & \\
\hline Mobil ; Mobil & 0 & 0 & 0 & - \\
Mobil ; Motor & 6 & 7 & 7 & $20(35,09)$ \\
Motor ; Motor & 6 & 8 & 3 & $17(29,82)$ \\
Motor ; Pejalan Kaki & 3 & 4 & 2 & $9(15,79)$ \\
Mobil ; Pejalan Kaki & 0 & 1 & 1 & $2(3,51)$ \\
Tunggal & 0 & 8 & 1 & $9(15,79)$ \\
Total & 15 & 28 & 14 & $57(100)$ \\
\hline
\end{tabular}

Tabel 8. Jumlah kasus kecelakaan lalu lintas dengan korban mati berdasarkan jenis kendaraan

\begin{tabular}{|c|c|c|c|c|c|}
\hline \multirow[t]{4}{*}{ Tahun } & \multicolumn{4}{|c|}{ Jenis Kendaraan } & \\
\hline & \multicolumn{3}{|c|}{ Bermotor } & \multirow{3}{*}{$\begin{array}{c}\text { Tak } \\
\text { Bermotor }\end{array}$} & \multirow{3}{*}{ Total } \\
\hline & Roda & Roda & $>4$ & & \\
\hline & Dua & 4 & & & \\
\hline 2012 & 11 & 0 & 0 & 0 & 11 \\
\hline 2013 & 25 & 0 & 0 & 0 & 25 \\
\hline 2014 & 10 & 0 & 1 & 0 & 11 \\
\hline Total & 46 & 0 & 1 & 0 & 47 \\
\hline$(\%)$ & 97,87 & - & 2,13 & - & 100 \\
\hline
\end{tabular}

Tabel 9. Jumlah kasus kecelakaan lalu lintas dengan korban mati berdasarkan hari kejadian

\begin{tabular}{c|c|c|c|c}
\hline \multirow{2}{*}{ Hari } & \multicolumn{3}{|c|}{ Tahun } & $\begin{array}{c}\text { Total } \\
(\%)\end{array}$ \\
\cline { 2 - 4 } & 2012 & 2013 & 2014 & $7(12,28)$ \\
Senin & 1 & 3 & 3 & $7(12,28)$ \\
Selasa & 2 & 3 & 2 & $7(12,28)$ \\
Rabu & 3 & 4 & 0 & $10(17,54)$ \\
Kamis & 2 & 3 & 5 & $6(10,53)$ \\
Jumat & 3 & 2 & 1 & $8(14,04)$ \\
Sabtu & 2 & 6 & 0 & $12(21,05)$ \\
Minggu & 2 & 7 & 3 & $57(100)$ \\
Total & 15 & 28 & 14 & \\
\hline
\end{tabular}


Tabel 10. Jumlah kasus kecelakaan lalu lintas dengan korban mati berdasarkan waktu kejadian

\begin{tabular}{c|c|c|c|c}
\hline \multirow{2}{*}{ Jam } & \multicolumn{3}{|c|}{ Tahun } & $\begin{array}{c}\text { Total } \\
(\%)\end{array}$ \\
\cline { 2 - 4 } & 2012 & 2013 & 2014 & $16(28,07)$ \\
\hline $06.00-12.00$ & 4 & 8 & 4 & $10(17,54)$ \\
$12.00-18.00$ & 4 & 4 & 2 & $24(42,11)$ \\
$18.00-00.00$ & 6 & 14 & 4 & $7(12,28)$ \\
$00.00-06.00$ & 1 & 2 & 4 & $57(100)$ \\
Total & 15 & 28 & 14 & \\
\hline
\end{tabular}

Tabel 11. Jumlah kasus kecelakaan lalu lintas dengan korban mati berdasarkan cuaca saat kejadian

\begin{tabular}{c|c|c|c|l}
\hline \multirow{2}{*}{ Cuaca } & \multicolumn{3}{|c|}{ Tahun } & \multicolumn{1}{c}{$\begin{array}{c}\text { Total } \\
(\%)\end{array}$} \\
\cline { 2 - 5 } & 2012 & 2013 & 2014 & \\
\hline Cerah & 10 & 25 & 6 & $41(71,93)$ \\
Mendung & 2 & 1 & 2 & $5(8,77)$ \\
Hujan & 3 & 1 & 3 & $7(12,28)$ \\
Berkabut & 0 & 1 & 3 & $4(7,02)$ \\
Total & 15 & 28 & 14 & $57(100)$ \\
\hline
\end{tabular}

Tabel 12. Jumlah kasus kecelakaan lalu lintas dengan korban mati berdasarkan lokasi kejadian

\begin{tabular}{c|c|c|c|c}
\hline \multirow{2}{*}{ Kecamatan } & \multicolumn{3}{|c|}{ Tahun } & \multirow{2}{*}{$\begin{array}{c}\text { Total } \\
(\%)\end{array}$} \\
\cline { 2 - 4 } & 2012 & 2013 & 2014 & - \\
Timur & 0 & 0 & 0 & $6(10,53)$ \\
Barat & 1 & 4 & 1 & $12(21,05)$ \\
Utara & 6 & 4 & 2 & $8(14,04)$ \\
Selatan & 0 & 5 & 3 & $16(28,07)$ \\
Tengah & 8 & 6 & 2 & $9(15,79)$ \\
Sonder & 0 & 6 & 3 & $6(10,53)$ \\
Tombariri & 0 & 3 & 3 & $57(100)$ \\
Total & 15 & 28 & 14 & \\
\hline
\end{tabular}

Tabel 13. Jumlah kasus kecelakaan lalu lintas dengan korban mati berdasarkan status jalan

\begin{tabular}{c|c|c|c|c}
\hline \multirow{2}{*}{ Status Jalan } & \multicolumn{3}{|c|}{ Tahun } & $\begin{array}{c}\text { Total } \\
(\%)\end{array}$ \\
\cline { 2 - 4 } & 2012 & 2013 & 2014 & $28(49,12)$ \\
\hline Dalam Kota & 10 & 13 & 5 & $20(35,09)$ \\
Luar / Antar Kota & 2 & 10 & 8 & $9(15,79)$ \\
Khusus & 3 & 5 & 1 & $57(100)$ \\
Total & 15 & 28 & 14 & \\
\hline
\end{tabular}

\section{BAHASAN}

Tabel 1 data jumlah kecelakaan lalu lintas mengalami kenaikan sekitar 12,28\% antara tahun 2012 - 2013 dan kemudian mengalami penuruan sekitar 13,75 \%. Dengan demikian, tahun 2013 merupakan puncak peningkatan jumlah kasus kecelakaan yang terjadi di kota Tomohon.
Hal ini berbanding terbalik dengan data keseluruhan kasus kecelakaan di Indonesia dari Kepolisian Republik Indonesia yang menjelaskan bahwa pada tahun 2013 walalupun kasus kecelakaan lalu lintas masih berada pada angka tinggi namun terjadi penurunan kasus kecelalaan lalu lintas sebesar 20,66 \%. ${ }^{12}$ Hal ini terkait 
Rompis, Mallo, Tomuka: Kematian akibat kecelakaan...

faktor kondisi sarana dan prasarana transportasi, faktor alam serta faktor manusia. Dari keempat faktor, kelalaian manusia menjadi penyebab tingginya kasus kecelakaan lalu lintas. Hal ini juga terkait dengan data dari Global Status Report On Road Safety tahun 2013 yang menyatakan bahwa terjadi peningkatan populasi kendaraan bermotor roda dua yang terjadi pada tahun $2013 .^{13}$

Tabel 2 memperlihatkan distribusi korban kecelakaan lalu lintas tertinggi oleh korban dengan luka ringan sebesar 535 orang dari 624 korban kecelakaan dibandingkan dengan jumlah korban luka berat maupun korban mati. Meskipun angka kecelakaan masih tinggi, namun jika dilihat dari data mengenai distribusi kerugian korban, terjadi perbedaan yang sangat signifikan antara korban luka ringan dengan korban mati dan

korban luka berat. Hal ini terkait dengan perilaku korban saat berkendara maupun pertolongan saat terjadi kecelakaan lalu lintas.

Tabel 3 menunjukan perbandingan angka kematian korban kasus kecelakaan berdasarkan jenis kelamin. Terlihat bahwa laki - laki sebagai korban mati terbanyak akibat kecelakaan lalu lintas di kota Tomohon periode 2012 - 2014 sebesar 84,75 \%. Hal ini sebanding dengan penelitian yang dilakukan Zella Manola tahun 2010 - 2011 dan Feibyg Lumandung tahun 2011 - 2012 di kota Manado sebesar $83,75 \%$ dan $82,4 \%{ }^{14,15}$ Hal ini terkait peran kaum laki - laki sebagai kepala keluarga yang dituntut untuk mencari nafkah dengan intensitas terbanyak di luar rumah. Hal ini mengakibatkan kaum laki laki menjadi populasi dominan di jalan raya. Selain itu, perilaku kaum laki - laki dalam berkendara juga merupakan faktor penentu tingginya angka kematian kaum laki - laki akibat kecelakaan lalu lintas.

Tabel 4 menunjukan distribusi korban mati akibat kecelakaan lalu lintas di kota Tomohon tahun 2012 - 2014. Dari data didapatkan bahwa korban terbanyak berada direntang usia 15 - 24 tahun. Hasil ini sebanding dengan data dari Direktorat
Jendral Perhubungan Darat yang menyatakan bahwa korban mati akibat kecelakaan lalu lintas tertinggi berada direntang usia 15 - 30 tahun. ${ }^{16}$ Kelompok usia 15 - 30 tahun termasuk dalam kategori dewasa muda dan kelompok usia produktif yang memiliki mobilitas tinggi sehingga sering tergesa - gesa dalam berkendara tanpa memperhatikan keselamatan berlalu lintas. Pada rentang usia ini cenderung memiliki tingkat emosi yang kurang stabil dibandingkan kelompok usia lebih dari 30 tahun yang lebih hati - hati, sadar bahaya dan lebih disiplin dalam berkendara. Menurut PP No. 44 Tahun 1993 tentang Kendaraan dan Pengemudi, memuat pasalpasal yang dapat dipandang sebagai perangkat lunak pengelolaan pengemudi. Pasal - pasal ini khusus memuat ketentuan - ketentuan bagi pengemudi menyangkut: penggolongan, persyaratan dan tata cara memperoleh Surat Izin Mengemudi (SIM), ujian bagi pemohon SIM, dan lain-lain termasuk ketentuan batas usia minimum hak mengemudi kendaraan bermotor, yaitu $:^{17}$

o Usia 16 tahun, dapat memiliki SIM - C o Usia 17 tahun, dapat memiliki SIM - A

o Usia 20 tahun, dapat memiliki SIM - B.I

untuk mengemudikan mobil bus dan mobil barang, dan SIM - B.II untuk mengemudikan traktor atau kendaraan bermotor dengan menarik kereta tempelan atau gandengan.

Tabel 5 menunjukan distribusi kasus kecelakaan dengan korban mati berdasarkan tingkat pendidikan. Hasil yang didapatkan, proporsi tertinggi korban dengan tingkat pendidikan SMA sederajat sebesar 52,54 \%. Hasil ini tidak sesuai dengan penelitian yang dilakukan di kota Manado tahun 2011 - 2012 yang menunjukan angka tertinggi yaitu 117 korban dengan pendidikan setingkat perguruan tinggi. ${ }^{14}$ Tingkat pendidikan berpengaruh pada program peningkatan secara langsung ataupun tidak langsung terhadap perilaku. Umumnya korban dengan pendidikan rendah sulit bekerja sama dan terbuka terhadap pembaharuan. Hal ini dikarenakan nilai - nilai lama yang 
masih dianut.

Tabel 6 menunjukan distribusi korban mati akibat kecelakaan lalu lintas berdasarkan peran korban sebelum mati. Berdasarkan hasil penelitian, angka tertinggi korban mati berstatus sebagai pengendara / pengemudi kendaraan bermotor dengan jumlah 40 orang dari 59 orang yang tercatat sebagai korban mati akibat kecelakaan di kota Tomohon sepanjang tahun 2012 - 2014. Hasil ini sebanding dengan hasil dari penelitian yang dilakukan di kota Manado periode 2011 2012 oleh Feibyg Lumandong yaitu sebesar 120 korban dari 188 kasus. ${ }^{14}$ Hal ini terkait perilaku pengendara dalam berlalu lintas. Perilaku yang dimaksud adalah kedisiplinan penggunaan atribut berkendara (sabuk pengaman, helm, kelengkapan surat, dll), kondisi psikis dan fisik (lelah, lengah, mengantuk, mabuk). Pengendara yang berada dibawah pengaruh alkohol dan obat - obatan cenderung memiliki risiko tinggi terjadi kecelakaan di lalu lintas. Hal ini terkait Alkohol sebagai Central Nervous System (CNS) depressant yang mempengaruhi keseimbangan antara eksitasi dan inhibisi di otak yang berefek sebagai disinhibisi, ataksia, dan sedasi.

Tabel 7 menggambarkan distribusi jenis tabrakan, menunjukan bahwa tabrakan antara motor dan mobil memiliki proporsi sebesar 35,09 \% sepanjang tahun 2012 2014. Sebanyak 20 kasus tabrakan antara mobil dan motor dari total 57 kasus tabrakan yang terjadi, korban kecelakaan yang mati hanya terbatas pada pengendara maupun penumpang kendaraan bermotor roda dua. Hal tersebut terlihat pada tabel 8 yang menunjukan proporsi 97,87 \% keterlibatan kendaraan sepeda motor. Jenis kendaraan terkait dengan perlengkapan, penerangan, pengamanan mesin kendaraan. Pengendara maupun penumpang kendaraan bermotor roda dua tidak dilindungi oleh perlengkapan pengamanan sebagaimana halnya pengendara mobil. Mereka hanya dilindungi oleh pakaian dan perlengkapan pengamanan yang dipakai langsung pada badannya, helm, sepatu, atau pakaian pelindung. Hanya helm yang mempunyai kemampuan untuk mendistribusikan transmisi energi dan mengurangi intensitas benturan. Hal ini dapat menurunkan angka kematian, kejadian trauma kepala berat dan pemendekan waktu perawatan. Trauma kepala juga merupakan penyebab kematian nomor satu (85\%) diantara penyebab kematian lain pada pengendara maupun penumpang sepeda motor. Derajat trauma yang dialami selama benturan bergantung pada tempat benturan, energi kinetik dari motor, dan interval waktu energi ini bekerja. Tempat benturan dapat dibagi menjadi tiga regio terbesar kepala yaitu regio frontalis, regio parietalis, dan regio temporalis. Pengendara sepeda motor yang mengalami cedera kepala paling rentan mengenai regio temporalis. Hal ini dikarenakan mekanisme trauma berupa laying the bike down yaitu manuver yang dilakukan pengendara untuk menghindari posisi terjepit antara kendaraan dan objek yang akan ditabraknya dengan menjatuhkan kendaraan ke samping. Jika jatuh dengan mekanisme ini akan terjadi trauma jaringan lunak yang parah seperti cedera pada regio temporalis karena terpisahnya lapisan periosteum duramater dengan tabula interna tulang tengkorak atau yang disebut perdarahan epidural yang sumber perdarahannya disebabkan karena robekan arteri - arteri meningea.

Sebanyak 47 total kendaraan yang terlibat kecelakaan dan menyebabkan kematian korban.Empat puluh enam diantaranya kendaraan bermotor roda dua. Sisanya kendaraan bermotor roda 6 jenis truck pengangkut material bangunan. Hasil penelitian ini relevan dengan penelitian yang dilakukan tahun 2010 dan 2011 di 6 provinsi pulau Jawa. Penelitian tersebut menunjukan bahwa terjadi peningkatan volume kendaraan sepeda motor sebanyak $30 \%$ yang langsung berpengaruh pada peningkatan interaksi antara kendaraan dan tingkat kemacetan di ruas - ruas jalan. Tahun 2011 di 6 provinsi pulau Jawa tercatat bahwa sebanyak $65 \%$ adalah jenis kendaraan bermotor roda 2 yang menjadi penyebab kecelakaan. ${ }^{18}$

Data dari Global Status Report On 
Road Safety tahun 2013, menyatakan bahwa 10 negara di Asia memiliki proporsi sepeda motor terbesar dari kendaraan lainnya. Hal ini terkait biayanya murah dapat dimiliki oleh kalangan ekonomi kelas menengah kebawah serta aksetabilitas yang tinggi. ${ }^{13}$

Tabel 9 menunjukan distribusi berdasarkan hari terjadinya kecelakaan di kota Tomohon periode 2012 - 2014. Proporsi tertinggi pada hari minggu sebesar 21,05 \%. Variabel hari terjadinya kecelakaan, berkaitan dengan volume lalu lintas kendaraan yang lewat di titik tertentu selama selang waktu tertentu. Varian hari dapat dikelompokan menjadi hari kerja (senin - kamis), hari minggu dan hari libur, serta akhir minggu (sabtu). Makin padat volume kendaraan, makin besar peluang terjadinya kecelakaan, namun terjadi pengurangan tingkat keparahan. Sebaliknya, semakin sedikit (sepi) volume kendaraan, peluang terjadinya kecelakaan kecil dengan tingkat keparahan yang tinggi.

Tabel 10 menggambarkan distribusi kecelakaan lalu lintas yang mengakibatkan kematian korban berdasarkan kelompok waktu. Dapat dikelompokan berdasarkan penerangan yaitu terang (pagi 06.00 12.00 dan siang 12.00 - 18.00) serta gelap (malam 18.00 - 00.00 dan dini hari 00.00 06.00). Hasil penelitian didapatkan proporsi tertinggi sebesar $42,11 \%$ pada malam hari pukul 18.00 - 00.00 WITA. Hasil ini tidak relevan dengan penelitian yang dilakukan Sayekti Utama tahun 2008 di Yogyakarta yang menyatakan kasus kecelakaan terbanyak terjadi antara pukul $06.00-12.00 .^{19}$ Hal ini terkait penerangan yang memengaruhi kondisi tubuh pengguna lalu lintas (penglihatan), pola aktivitas populasi penduduk di daerah terkait. Malam hari dengan minim pencahayaan ruas jalan (lampu penerang jalan) pengendara mengalami kesulitan melihat ataupun dilihat (oleh pengendara lain) jelas. Bahkan dengan penerangan lampu depan kendaraan, pengendara masih sulit melihat kondisi dan situasi jalan serta pengendara lain pun kesulitan melihat lampu depan dan belakang karena terhalang oleh kendaraan yang berada di depan. Pagi hari sekitar pukul 06.00 - 12.00, masyarakat memulai segala aktivitas, sehingga peluang terjadinya kecelakaan lebih besar.

Tabel 11 menggambarkan pengaruh cuaca terhadap peningkatan angka kecelakaan lalu lintas dengan korban mati di kota Tomohon periode 2012 - 2014. Cuaca cerah saat kejadian kecelakaan lalu lintas memiliki proporsi tertinggi sebesar $71,93 \%$. Cuaca berpengaruh terhadap permukaan jalan yaitu kering (cerah dan mendung) dan basah (hujan dan gerimis). Selain itu, cuaca juga berhubungan dengan kondisi tubuh (panca indra) dan emosi. Pada udara panas, pengguna jalan cenderung cepat marah dan mengemudikan kendaraan dengan kecepatan tinggi. Saat hujan, pengendara kekurangan kontrol akibat kondisi jalan yang licin sehingga mengemudikan kendaraan dengan kecepatan rendah dan hati - hati.

Tabel 12 menggambarkan distribusi lokasi tersering terjadinya kecelakaan lalu lintas dengan korban mati di kota Tomohon tahun 2012 - 2014 di wilayah kecamatan Tomohon Tengah dengan proporsi 28,07\%.

Tabel 13 yang menggambarkan proporsi tertinggi kasus kecelakaan berdasarkan status jalan sekitar 49,12 \% pada jalan dalam kota. Hal ini berhubungan dengan terpusatnya sebagian besar pusat layanan umum dan pemerintahan di wilayah Kecamatan Tomohon Tengah. Keadaan ini memengaruhi pengemudi dalam mengatur kecepatan (mempercepat, konstan, memperlambat, berhenti). Terkait juga dengan kondisi tempat kejadian seperti tata guna lahan, cuaca, peraturan lalu lintas pada ruas jalan, volume kendaraan, komposisi lalu lintas dan perencana jalan (persimpangan, struktur penerangan, posisi bangunan, kerusakan jalan, dll).

\section{SIMPULAN}

Berdasarkan data hasil penelitian di Bagian Lalu Lintas Polresta Tomohon tentang kematian akibat kecelakaan lalu lintas di Kota Tomohon tahun 2012 - 2014 disimpulkan bahwa: 
1. Tahun 2013 merupakan puncak kenaikan angka kecelakaan lalu lintas yang terjadi di kota Tomohon

2. Jumlah korban yang meninggal terbanyak ialah jenis kelamin laki laki, berpendidikan SMA sederajat, usia produktif, serta pengendara sepeda motor.

3. Dari 407 kasus kecelakaan yang terjadi di kota Tomohon, hanya 57 kasus kecelakaan lalu lintas dengan korban mati. Proporsi tertinggi tabrakan antara mobil dan motor terjadi pada hari Minggu antara pukul $18.00-00.00$ WITA, di jalan kota dan pada cuaca cerah.

\section{SARAN}

1. Perlu dilakukan sosialisasi prevalensi angka kematian akibat kecelakaan lalu lintas sehingga dapat dilakukan upaya - upaya terkait dalam pencegahan kasus kecelakaan lalu lintas seperti pengadaan penyuluhan kepada masyarakat terutama pada kaum muda usia produktif mengenai kesadaran berlalu lintas serta risiko dampak kecelakaan lalu lintas.

2. Perlu dibentuk sistem surveilans terpadu kecelakaan lalu lintas khususnya di kota Tomohon dengan melibatkan instansi kepolisian dan kesehatan serta instansi terkait lainnya sehingga dapat diperoleh data kecelakaan lalu lintas yang lebih akurat.

3. Diharapkan pihak kepolisian lebih tertib dalam pemberian Surat Izin Mengemudi sesuai persyaratan yang ada, perketat pengawasan penggunaan sabuk pengaman dan penggunaan helm serta harus diberi sanksi yang tegas jika melanggar peraturan.

4. Pemerintah diharapkan lebih memperhatikan fasilitas sarana dan prasarana lalu lintas di kota Tomohon serta diharapkan alokasi pendistribusiannya merata ke seluruh wilayah kota Tomohon.

5. Diperkirakan tahun 2020 kasus kecelakaan lalu lintas akan menjadi peringkat ke 3 penyebab kecacatan terbanyak di dunia. Oleh karena itu sebaiknya pusat-pusat pelayanan kesehatan dapat meningkatkan pelayanan korban saat terjadi kecelakaan sehingga dapat mencegah kematian pada korban kecelakaan lalu lintas. Sebaiknya, korban kecelakaan lalu lintas perlu dilakukan autopsi, untuk menemukan penyebab pasti dan untuk kepentingan peradilan.

6. Untuk orang tua diharapkan tetap melakukan pengawasan yang ketat bagi anak-anak agar anak-anak dibawah umur tidak mengendarai kendaraan bermotor serta tetap melakukan pengawasan terhadap pendidikan dan lingkungan pergaulan anak.

\section{DAFTAR PUSTAKA}

1. World Health Organization. Time For Action. Departement of Injuries and Violence Prevention Noncommunicable Diseases and Mental Health Cluster World Health Organization. Geneva: WHO; 2009.

2. Oktaviana F. Pola Cedera Kecelakaan Lalu Lintas pada Kendaraan Beroda Dua. [diakses tanggal 15 september 2015]. Available from: www.lontar.ui.ac.id/file?file S-5384Pola\%20cidera-Bibliografi.pdf.

3. Badan Pusat Statistik. Banyaknya Kecelakaan Lalu Lintas Menurut Akibat Kecelakaan dan Nilai Kerugian Menurut Kabupaten/Kota di Bali Tahun 2011. [diakses tanggal 15 september 2015]. Available from: bali.bps.go.id/tabel_detail.php?ed=60 $6014 \&$ od $=6 \& i d=6$.

4. Samir H, Yaseen MA. Critical Care Management Of Severe Traumatic Brain Injury in Adults. Journal Of Trauma Resuscitation and Emergency Medicine. 2012. http://www.sjtrem.com/content/

5. Peden M, Scurfield R, Sleet D, Mohan D, Hyder AA, Jarawan E, et al. World report on road traffic injury prevention. Geneva: WHO; 2004.

6. Suwandono A. Road traffic collision in urban Indonesia, epidemiology and 
policy opportunities. Jakarta: Badan Penelitian dan Pengembangan Kesehatan, Departemen Kesehatan RI; 2002

7. Wedasana SA. Analisis Daerah Rawan Kecelakaan dan Penyusunan Database berbasis Sistem Informasi Geografis. [diakses 15 september 2015]. Available from: www.pps.unud.ac.id/.../unud314345621820agus\%20surya(079256 1052),pdf.

8. Direktorat Lalu Lintas Kepolisian Republik Indonesia (Ditlantas POLRI). Prevensi dan reduksi kecelakaan sepeda motor di jalan raya. Makalah Diskusi Penyusunan Sistem Surveilans Cedera Akibat Kecelakaan Lalu Lintas pada Pengendara Sepeda Motor.15 Agustus 2005.

9. Holder Y, Peden M, Krug E, Lund J, Gururaj G, Kobusingye O. Injury surveillance guidelines. Geneva: World Health Organization; 2001

10.Feibyg L. Gambaran Korban meninggal dengan cedera kepala pada kecelakaan lalu lintas di bagian Forensik BLU RSUP Prof. Dr. R. D. Kandou Manado periode 2011 - 2012 [skripsi]. Manado: FK-Unsrat; 2011.

11.Tomohon City. Situs Resmi Pemerintah Kota Tomohon [internet].2015 [update 2015; cited Jan 2016]. Available from : http://www.tomohonkota.go.id

12.Sutiawan I. Pada 2013, 23.385 Tewas Kecelakaan Lalu Lintas. 2013. http://www.gatra.com/hukum-1/4450- pada-2013,-23-385-tewas-

kecelakaan-lalu-lintas

13.World Health Organization. Statistic Of Road Traffic Accident. Geneva: WHO;2013

14.Feibyg L. Gambaran Korban meninggal dengan cedera kepala pada kecelakaan lalu lintas di bagian Forensik BLU RSUP Prof.Dr.R.D.Kandou Manado periode 2011 - 2012.[skripsi].[Manado]:FKUNSRAT; 2011

15.Zella A. Pola luka pada kasus kecelakaan lalu lintas BLU RSUP Prof.Dr.R.D.Kandou Manado periode 2010 - 2011.[skripsi].[Manado]: FKUNSRAT; 2011

16.Departemen Perhubungan. Kecelakaan lalu lintas tempati urutan ketiga penyebab kematia,.2011. Available from:http://m.dephub.go.id/read/berit a/direktorat-jenderal-perhubungandarat/kecelakaan-lalu-lintas-tempatiurutan-tiga-penyebab-kematian-5313. [Accesed 3 December 2015]

17.Pemerintah Republik Indonesia.Peraturan Pemerintah Nomor 43 Tahun 1993 tentang Prasarana dan Lalu Lintas Jalan. Jakarta;1993

18.Najid. Estimasi Tingkat Kecelakaan Lalu Lintas Nasional Dan 6 Provinsi Di Pulau Jawa Indonesia [skripsi]. Jakarta: Fatek Untar; 2013.

19.Utama S, Magetsari R, Pribadi V. Estimasi Prevalensi Kecelakaan Lalu Lintas dengan Metode Capture Recapture. Berita Kedokteran Masyarakat. 2008;24(1). 